\title{
Perception towards Artificial Intelligence in Human Resources Management Practices -with Reference to IT Companies in Chennai
}

\author{
P. Barani Kumari, A. Hemalatha
}

\begin{abstract}
Artificial intelligence is a discrete branch of science and technology which has been exercised constructively over the past 60 years in various fields. While artificial intelligence is making its mark in almost all areas, human resources practices arenot an exception. Human resource management is one crucial area in each organization and it is essential to realize that people who are part of human resource management have to be familiar with the notion of Artificial intelligence. Some HR experts suppose that upgraded and advanced AI is a threat to human community and in the upcoming decades AI would significantly reduce the demand for human resource globally. In contrast, some researchers believe that $A I$ is one of the sophisticated tools meant to assist humans and it can never ever replace human labor. Having in mind the above points, the main purpose of this research is to investigate employee's perception towards Artificial Intelligence technologies in human resources practices.The method used for data collection was the online survey and the tool used was the questionnaire. Along with the focus on the participant's perception of AI, and the study also aims to understand the current AI technologies being practiced in Human Resources practices.
\end{abstract}

Keywords : Perception, Artificial intelligence technologies, Human resources practices.

\section{INTRODUCTION}

The adoption of technology has reached a point where we are ready for a radical shift, and this digital transformation of the industry is something we call as Industry 4.0. Industry 4.0 which is also known as the intelligent industry is considered to be the fourth industrial revolution. The term fourth industrial revolution coined by Professor Schwab and seeks to transmute an organisation into an intelligent one to achieve the best possible business results. This in turn paved way for inclusion of disruptive technologies such Artificial intelligence and its subsets in almost all functional areas of management and Human resource management is not an exception. How will these disruptive technologies transform our lives? Will our workplaces be impacted by the emergence and implementation of AI entities? What are the AI

Revised Manuscript Received on December 05, 2019.

* Correspondence Author

Dr. P. Bharani Kumari*, Assistant Professor and Head, Department of Commerce, Sri Kaniyaka Parameshwari Arts \& Science College for Women, Chennai.

A. Hemalatha, Research Scholar and Assistant Professor, Department of Commerce, Sri Kaniyaka Parameshwari Arts \& Science College for Women, Chennai. technologies in use to augment human force? The current study attempts to investigate HR professional's and employee's perception of Artificial Intelligence technologies in human resources practices. The study focuses on the participant's perception of AI, and also aims to understand the current AI technologies being practiced in Human Resource departments.

\section{LITERATURE REVIEW}

An endeavour has been made to provide an outline and overview of various aspects of this study through the review of past and current existing literature. The sources referred include various books, doctoral theses, online journals, working papers, reports, magazines related to AI and human resource, internet sites and newspapers.

Vasile Gherhes 2018 has stated in his article "Artificial Intelligence: Perception, expectations, hopes and benefits" that AI can generate concrete benefits in the future. He has stressed that future will be with the development of AI sophisticated robots and totally assertive that new hobs will emerge. The job issue in the sense that people being replaced by robots is debated intensely nowadays, and his study addressed this replacement will lead to the creation of new jobs with new skill sets, to the emergence of new trades. He concluded that even though the emergence and growth of AI is seen as a danger to life and jobs, the real objective of AI is to ease our work more efficient, make lives comfortable and solve complex problems which the society is about to face.

DariaFagerli 2018 in his thesis "Various perspectives on the consequences of Artificial intelligence for our professional life" has recommended new laws and regulations ensuring that $\mathrm{AI}$ processes does not harm society in general on political perspective and has advocated that everyone ought to gain digital knowledge on personal perspective. He has stated that AI and other new technologies have gained significant momentum during the recent few years. As the result of increasing interest, there is going to be a lot of research in this field. As this field of study is highly characterized by uncertainty with many different predictions, projections and anticipations, there are still plenty of areas that could be researched. He has suggested future research on ethical, moral or philosophical question connected to the

Published By:

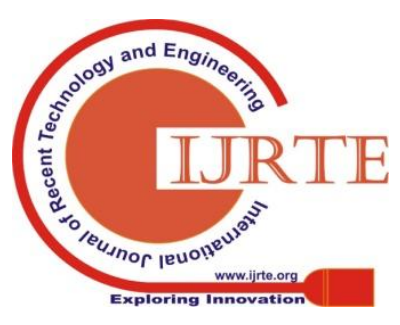


creation of super intelligence, study the perspectives on the regulations and finally consequences of digital transformation for gender equality.

Jiachao Fang, Hanning Su, and Yuchong Xiao 2018have conducted an initial search of existing literature to definitions of Human intelligence and artificial intelligence. They have also classified different types of AI and analysed their performance individually. Finally, they concluded whether AI will surpass $\mathrm{HI}$ in the future. They stated we cannot say machines have surpassed humans since their cognitive abilities such as emotion recognition and creativity. Lastly, they have mentioned AI will definitely surpass humanity in any sense on the day when superintelligence emerges from being a mere hypothesis to reality. They have recommended continuous effort is required to study performance of $\mathrm{AI}$ and comparisons between $\mathrm{AI}$ and $\mathrm{HI}$.

Lucas KromannBogehoj Nielson 2016 in his discussion paper on "Artificial Intelligence, Human Intelligence and the rapid transformation of digitalization and datafication that our current society is going through" has explained relevant concepts such as Big Data (BD), datafication and algorithms. $\mathrm{He}$ has discussed about what constitutes machine intelligence, and how it is different from human intelligence by means of the Turing test. Lastly, he has stressed about personal fears and its reflections. He stated he do not believe robots will turn evil and destroy us, but he fears that people are losing more grip of reality the more ease of life they achieve.

\section{RESEARCH METHODOLOGY}

Primary data and secondary data have been subsequently used in the study. The present study was done through a quantitative approach, based on the sociological survey method. The questionnaire is the data collection tool which was used via Google forms platform (an online survey service). The respondents were both HR employees and HR professional from IT sector with reference to Chennai. Sample size denotes the number of sample selected for the study. The sample size for this study is fixed at 50 respondents. Based on simple random sampling method and convenience sampling method 50 respondents were chosen from the company. The other relevant information and data were collected from secondary sources also, such as books, websites, journals and publications. A structured questionnaire with 34 questions with 7 personal questions, 4 multiple choice questions and 23 five point scale questions was designed. The questionnaire was indeed discussed with a statistician and changes were accommodated.

\section{SCOPE OF THE STUDY}

This study enables to have fair knowledge about the various AI technologies being applied in human resource management practices and to understand the respondent's perception about AI technologies in HRM practices. An attempt is made to find out the impact of AI-powered HR factors on the work-life balance.

\section{OBJECTIVE OF THE STUDY}

1. To identify the current AI technologies being applied in human resources practices.

2. To understand participant's perception about AI

\section{LIMITATIONS OF THE STUDY}

1. The study may be applicable only to IT companies subject to Chennai.

2. The survey has been conducted only among $50 \mathrm{HR}$ employees of the IT companies.

3. The period of the study is limited and hence it may not be able to cover the entire scope.

4. The research pertains to 2018-2019 and data have been collected from the present employees, so it may vary in the future.

\section{DATA ANALYSIS AND INTERPRETATION}

In this chapter an in depth study has been made to identify the various AI technologies being used in IT sector and to understand their perception towards AI technologies in HRM practices. For this purpose, primary data was collected from 50 respondents by way of convenience sampling. The data were analyzed by using statistical tools like percentages, mean, T test, one-way ANOVA test.

\section{A. Cronbach's Alpha Reliability Statistics}

Table 1: Reliability Statistics

\begin{tabular}{|c|c|}
\hline Cronbach's Alpha & N of items \\
\hline .857 & 50 \\
\hline \multicolumn{2}{|c|}{ Source: Computed } \\
\hline
\end{tabular}

The primary data from the respondents were tested for reliability using SPSS. The Cronbach's Alpha test revealed a reliability score of 0.857 and hence the questionnaire was found to be reliable.

\section{B. Demographics}

It is vital to categorize the respondent's demographic profile because it gives a broad picture and helps to analyze the demographic factors which may influence their perception towards AI technologies in HRM practices.

Table - 2: Demographics

\begin{tabular}{|l|c|c|}
\hline \multicolumn{1}{|c|}{ Demographics } & Frequency & Percentage \\
\hline Age & & \\
\hline 22-25 years & 10 & 20 \\
\hline 26-30 years & 11 & 22 \\
\hline 31-40 years & 19 & 38 \\
\hline Above 40 years & 10 & 20 \\
\hline Gender & & \\
\hline Male & 19 & 38 \\
\hline Female & 31 & 62 \\
\hline Marital Status & & \\
\hline Single & 17 & 34 \\
\hline Married & 33 & 66 \\
\hline
\end{tabular}




\begin{tabular}{|l|c|c|}
\hline \multicolumn{1}{|c|}{ Demographics } & Frequency & Percentage \\
\hline Work Experience & & \\
\hline Less than 2 years & 9 & 18 \\
\hline 2-5 years & 12 & 24 \\
\hline 6-10 years & 11 & 22 \\
\hline 11-15 years & 8 & 16 \\
\hline Educational Qualification & & \\
\hline Doctoral Degree & 10 & 20 \\
\hline Master's Degree & 8 & 16 \\
\hline Bachelor's Degree & 25 & 50 \\
\hline Diploma & 15 & 30 \\
\hline Others & 2 & 4 \\
\hline Designation & 13 & 26 \\
\hline Administrator & 10 & 20 \\
\hline Business and Program Analyst & 9 & 18 \\
\hline Engineer(Automation \&Software) & 11 & 22 \\
\hline Project and HR manager & 2 & 4 \\
\hline Managing Director & 5 & 10 \\
\hline Others & & \\
\hline
\end{tabular}

automation, data mining, virtual assistance, robotics, Machine \& Natural language learning, DSS and Expert system, Block-chain and finally Predictive analytics. It is very clear from the above analysis that awareness towards AI technologies in HRM is limited.

Table - 4: Age wise Perception towards AI technologies in Human resource practices - ANOVA

\begin{tabular}{|c|c|c|c|c|c|c|}
\hline $\begin{array}{c}\text { HR } \\
\text { factor/Age } \\
\text { groups }\end{array}$ & $22-25 \mathrm{yrs}$ & $26-30 \mathrm{yrs}$ & $\begin{array}{c}31-40 \\
\mathrm{yrs}\end{array}$ & $\begin{array}{l}\text { Above } \\
40 \text { yrs }\end{array}$ & F & $P$ \\
\hline $\begin{array}{l}\text { Planning\& } \\
\text { DM }\end{array}$ & $\begin{array}{l}16.00 \\
(2.31)\end{array}$ & $\begin{array}{l}16.09 \\
(1.81)\end{array}$ & $\begin{array}{l}16.78 \\
(1.81)\end{array}$ & $\begin{array}{l}16.10 \\
(2.13)\end{array}$ & .53 & .66 \\
\hline Recruitment & $\begin{array}{l}18.80 \\
(4.16)\end{array}$ & $\begin{array}{l}18.18 \\
(3.28)\end{array}$ & $\begin{array}{l}20.21 \\
(2.04)\end{array}$ & $\begin{array}{l}17.40 \\
(4.30)\end{array}$ & 1.84 & .15 \\
\hline $\begin{array}{l}\text { Training \& } \\
\text { Development }\end{array}$ & $\begin{array}{l}20.30 \\
(4.11)\end{array}$ & $\begin{array}{l}19.27 \\
(2.53)\end{array}$ & $\begin{array}{l}20.31 \\
(2.42)\end{array}$ & $\begin{array}{l}20.30 \\
(4.19)\end{array}$ & .29 & .83 \\
\hline $\begin{array}{l}\text { Performance } \\
\text { Analysis }\end{array}$ & $\begin{array}{l}20.00 \\
(4.39)\end{array}$ & $\begin{array}{l}19.18 \\
(2.09)\end{array}$ & $\begin{array}{l}19.84 \\
(2.75)\end{array}$ & $\begin{array}{l}20.300 \\
(2.16)\end{array}$ & .27 & .84 \\
\hline $\begin{array}{l}\text { Work-life } \\
\text { Balance }\end{array}$ & $\begin{array}{l}14.90 \\
(2.33)\end{array}$ & $\begin{array}{l}14.72 \\
(2.76)\end{array}$ & $\begin{array}{l}16.21 \\
(2.32)\end{array}$ & $\begin{array}{l}15.40 \\
(3.17)\end{array}$ & .97 & .41 \\
\hline
\end{tabular}

Interpretation: The demographic factors like age, gender, marital status, working experience, educational qualifications, and designation are to be studied to understand the sample better. The respondents included male and female. The respondents belonged to different age groups but majority being 31 years to 40 years (38\%). Hence, middle age people participated in the survey more willingly than the young people. The sample included literates of all levels mostly bachelor's degree holders $(50 \%)$ and diploma holders $(30 \%)$. Majority of the respondents were married $(66 \%)$ and employment designation mostly Administrator (26\%) and secondly Project and HR managers (22\%).

\section{Table - 3: AI powered HRM technologies which IT} employees are aware about

\begin{tabular}{|l|c|c|c|}
\hline \multicolumn{1}{|c|}{ AI technologies } & Frequency & Percentage & Ranking \\
\hline Chatbots & 17 & 34 & VII \\
\hline $\begin{array}{l}\text { Face recognition\& Bio } \\
\text { metrics }\end{array}$ & 34 & 68 & I \\
\hline Data Mining & 21 & 42 & V \\
\hline Big Data Analytics & 12 & 48 & III \\
\hline $\begin{array}{l}\text { Speech \&Voice } \\
\text { recognition }\end{array}$ & 31 & 62 & II \\
\hline Virtual Assistance & 18 & 36 & VI \\
\hline Automation & 22 & 44 & IV \\
\hline $\begin{array}{l}\text { Machine and Natural } \\
\text { language learning }\end{array}$ & 15 & 30 & VIII \\
\hline Block-Chain & 11 & 22 & X \\
\hline Robotics & 18 & 36 & VI \\
\hline $\begin{array}{l}\text { Decision support system } \\
\text { and Expert system }\end{array}$ & 12 & 24 & IX \\
\hline Predictive analytics & 10 & 20 & XI \\
\hline
\end{tabular}

Interpretation: Out of all AI technologies being applied in HRM practices, firstly, $68 \%$ of employees have identified face recognition \& Biometric technology, secondly $62 \%$ of employees have identified speech \& voice recognition technology, thirdly Big data analytics with $48 \%$, followed by

Table - 5: Gender wise Perception towards AI

technologies in Human resource practices - t-test

\begin{tabular}{|c|c|c|c|c|}
\hline HR factor/Gender & Male & Female & F & P \\
\hline Dlanning\& & $\begin{array}{c}16.57 \\
(1.609)\end{array}$ & $\begin{array}{c}16.19 \\
(2,151)\end{array}$ & .749 & .391 \\
\hline Recruitment & $\begin{array}{c}18.21 \\
(2.916)\end{array}$ & $\begin{array}{c}19.35 \\
(3.638)\end{array}$ & .413 & .523 \\
\hline $\begin{array}{c}\text { Training \& } \\
\text { Development }\end{array}$ & $\begin{array}{c}19.42 \\
(2.292)\end{array}$ & $\begin{array}{c}20.48 \\
(3.567)\end{array}$ & 4.562 & .038 \\
\hline $\begin{array}{c}\text { Performance } \\
\text { Analysis }\end{array}$ & $\begin{array}{c}19.84 \\
(2.587)\end{array}$ & $\begin{array}{c}19.80 \\
(3.070)\end{array}$ & .497 & .484 \\
\hline Work-life Balance & $\begin{array}{c}15.00 \\
(2.472)\end{array}$ & $\begin{array}{c}15.74 \\
(2.682)\end{array}$ & .564 & .456 \\
\hline
\end{tabular}

Interpretation: From the above table, since the $\mathrm{P}$ values are greater than 0.05 it reveals that there is no significant mean difference between gender and employee's perception towards AI technologies in $\mathrm{HR}$ practices. There is no significant difference between perception on AI technologies with the gender of employees and both of them perceived it similar.

Table - 6: Perception towards AI technologies in Human resource practices based on Educational Qualification -

\begin{tabular}{|c|c|c|c|c|c|c|}
\hline $\begin{array}{l}\mathrm{HR} \\
\text { factor/Educational } \\
\text { Qualification }\end{array}$ & $\begin{array}{l}\text { Doctoral } \\
\text { degree }\end{array}$ & $\begin{array}{l}\text { Master's } \\
\text { degree }\end{array}$ & $\begin{array}{l}\text { Bachelor's } \\
\text { degree }\end{array}$ & Diploma & $\mathrm{F}$ & $\mathrm{P}$ \\
\hline $\begin{array}{l}\text { Planning\& } \\
\text { DM }\end{array}$ & $\begin{array}{c}17.12 \\
(2.031)\end{array}$ & $\begin{array}{c}16.32 \\
(1.994)\end{array}$ & $\begin{array}{c}15.86 \\
(1.922)\end{array}$ & $\begin{array}{c}17.00 \\
(1.414)\end{array}$ & .790 & .506 \\
\hline Recruitment & $\begin{array}{c}19.50 \\
(3.927)\end{array}$ & $\begin{array}{c}19.52 \\
(2.518)\end{array}$ & $\begin{array}{c}17.20 \\
(3.985)\end{array}$ & $\begin{array}{c}22.00 \\
(2.828)\end{array}$ & 2.345 & .085 \\
\hline
\end{tabular}


Perception towards Artificial Intelligence in Human Resources Management Practices -with Reference to IT Companies in Chennai

\begin{tabular}{|c|c|c|c|c|c|c|}
\hline $\begin{array}{l}\text { Training } \quad \& \\
\text { Development }\end{array}$ & $\begin{array}{r}21.00 \\
(3.023)\end{array}$ & $\begin{array}{c}20.20 \\
(3.135)\end{array}$ & $\begin{array}{c}19.13 \\
(3.204)\end{array}$ & $\begin{array}{c}22.00 \\
(4.242)\end{array}$ & .928 & .435 \\
\hline $\begin{array}{l}\text { Performance } \\
\text { Analysis }\end{array}$ & $\begin{array}{c}20.75 \\
(2.251)\end{array}$ & $\begin{array}{c}19.24 \\
(3.218)\end{array}$ & $\begin{array}{c}19.93 \\
(2.344)\end{array}$ & $\begin{array}{c}22.50 \\
(3.535)\end{array}$ & 1.227 & .311 \\
\hline Work-life Balance & $\begin{array}{c}18.00 \\
(2.203)\end{array}$ & $\begin{array}{c}15.32 \\
(2.286)\end{array}$ & $\begin{array}{c}14.06 \\
(2.433)\end{array}$ & $\begin{array}{c}17.50 \\
(0.7071)\end{array}$ & 5.653 & .002 \\
\hline
\end{tabular}

qualification and their perception towards AI technologies in HR practices except the factor Work-life balance. Since the $P$ value of work-life balance is less than 0.05 there is significant association between educational qualification and their perception towards AI technologies to attain work-life balance.

Interpretation: The above table reveals that there is no significant association between respondent's educational

Table - 7: Perception towards AI technologies in Human resource management based on Designation - ANOVA

\begin{tabular}{|c|c|c|c|c|c|c|c|c|}
\hline HR factor/Designation & Administrator & $\begin{array}{c}\text { Business and } \\
\text { Program } \\
\text { Analyst }\end{array}$ & $\begin{array}{c}\text { Software } \\
\text { engineer } \\
\text { (Automation) }\end{array}$ & $\begin{array}{l}\text { Project and HR } \\
\text { Manager }\end{array}$ & $\begin{array}{l}\text { Managing } \\
\text { Director }\end{array}$ & Others & $\mathrm{F}$ & $\mathrm{P}$ \\
\hline $\begin{array}{l}\text { Planning\& } \\
\text { DM }\end{array}$ & $\begin{array}{c}16.69 \\
(2.250)\end{array}$ & $\begin{array}{c}16.10 \\
(2.024)\end{array}$ & $\begin{array}{c}16.33 \\
(1.732)\end{array}$ & $\begin{array}{c}16.09 \\
(1.414)\end{array}$ & $\begin{array}{c}17.00 \\
(1.414)\end{array}$ & $\begin{array}{c}16.20 \\
(3.193)\end{array}$ & .184 & .967 \\
\hline Recruitment & $\begin{array}{c}20.30 \\
(4.028)\end{array}$ & $\begin{array}{c}18.50 \\
(3.135)\end{array}$ & $\begin{array}{c}16.88 \\
(3.855)\end{array}$ & $\begin{array}{c}19.36 \\
(2.419)\end{array}$ & $\begin{array}{c}17.50 \\
(2.121)\end{array}$ & $\begin{array}{c}19.40 \\
(2.701)\end{array}$ & 1.269 & .294 \\
\hline Training \& Development & $\begin{array}{c}21.38 \\
(3.905) \\
\end{array}$ & $\begin{array}{c}20.40 \\
(2.633) \\
\end{array}$ & $\begin{array}{c}17.77 \\
(2.948) \\
\end{array}$ & $\begin{array}{c}20.18 \\
(2.182) \\
\end{array}$ & $\begin{array}{c}20.50 \\
(.7071) \\
\end{array}$ & $\begin{array}{c}19.80 \\
(3.701) \\
\end{array}$ & 1.510 & .206 \\
\hline Performance Analysis & $\begin{array}{c}21.07 \\
(3.751)\end{array}$ & $\begin{array}{c}18.90 \\
(2.685)\end{array}$ & $\begin{array}{c}19.88 \\
(1.269)\end{array}$ & $\begin{array}{c}19.36 \\
(3.074)\end{array}$ & $\begin{array}{l}20.00 \\
(.000)\end{array}$ & $\begin{array}{c}19.20 \\
(2.683)\end{array}$ & .792 & .561 \\
\hline Work-life Balance & $\begin{array}{c}16.23 \\
(2.773)\end{array}$ & $\begin{array}{c}16.10 \\
(1.969)\end{array}$ & $\begin{array}{c}14.33 \\
(2.449)\end{array}$ & $\begin{array}{c}15.00 \\
(1.843)\end{array}$ & $\begin{array}{c}13.00 \\
(4.024)\end{array}$ & $\begin{array}{c}16.20 \\
(4.024)\end{array}$ & 1.218 & .317 \\
\hline
\end{tabular}

Interpretation: The above table reveals that there is no significant association between respondent's designation and their perception towards AI technologies in HR practices.

Table - 8: Job elements that can be outsourced to AI-powered digital assistants

\begin{tabular}{|l|c|c|c|}
\hline \multicolumn{1}{|c|}{ Job Elements } & Frequency & Percentage & Ranking \\
\hline Billing and expenses & 29 & 58 & III \\
\hline $\begin{array}{l}\text { Accounting and tracking } \\
\text { financials }\end{array}$ & 25 & 50 & V \\
\hline Writing proposals & 14 & 28 & VII \\
\hline Setting up employee benefits & 17 & 34 & VI \\
\hline $\begin{array}{l}\text { Management with } \\
\text { employees }\end{array}$ & 7 & 14 & VIII \\
\hline Repetitive paper works & 34 & 68 & I \\
\hline $\begin{array}{l}\text { Scheduling/updating } \\
\text { Calendar }\end{array}$ & 27 & 54 & IV \\
\hline Entering timesheet hours & 27 & 54 & IV \\
\hline $\begin{array}{l}\text { Writing and responding to } \\
\text { emails }\end{array}$ & 17 & 34 & VI \\
\hline Work/place surveillance & 32 & 64 & II \\
\hline
\end{tabular}

Interpretation: The above table demonstrates the job elements that can be outsourced to AI-powered digital assistants. $68 \%$ of respondents are positive about using AI digital assistants for repetitive paper works, $64 \%$ have voted for workplace surveillance, $58 \%$ has opted billing and expenses, $54 \%$ have preferred scheduling/updating calendar and entering timesheet hours.

Table - 9: Factors Holding back business leaders from implementing AI systems in their organisations

\begin{tabular}{|l|c|c|c|}
\hline Factors holding back AI & Frequency & Percentage & Ranking \\
\hline High Costs & 36 & 72 & I \\
\hline Lack of technical ability & 31 & 62 & II \\
\hline Lack of quality data & 14 & 28 & VI \\
\hline Privacy concerns & 22 & 44 & III \\
\hline Concerns of trust & 18 & 36 & V \\
\hline $\begin{array}{l}\text { Lack of skilled teams to } \\
\text { manage }\end{array}$ & 21 & 42 & IV \\
\hline
\end{tabular}

Interpretation: The above table shows the factors which are holding back business leaders from successfully integrating AI systems in their organisations. It has been found that the first and foremost factor is its High cost with $72 \%$, secondly Lack of technical ability with $62 \%$, and thirdly privacy concerns with $44 \%$.

Table - 10: Overall perception about implementing AI in human resource management probably man-machine collaboration

\begin{tabular}{|r|l|l|l|l|}
\hline & Frequency & Percent & $\begin{array}{l}\text { Valid } \\
\text { Percent }\end{array}$ & $\begin{array}{l}\text { Cumulative } \\
\text { Percent }\end{array}$ \\
\hline Valid yes & 45 & 90.0 & 90.0 & 90.0 \\
No & 5 & 10.0 & 10.0 & 100.0 \\
Total & 50 & 100.0 & 100.0 & \\
\hline
\end{tabular}

Interpretation: Finally, when respondents were questioned about implementing AI in HR practices and do they agree that future of HR will most probably Man-machine collaboration $90 \%$ of respondents have responded positive and have supported AI technologies in HR practices and only $10 \%$ of the respondents are against the AI technologies.

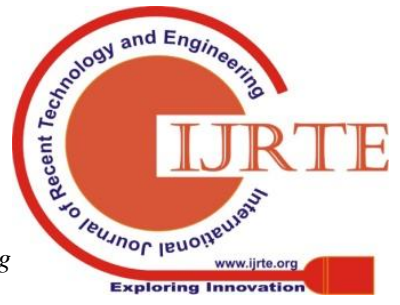




\section{FINDINGS AND CONCLUSION}

The study has put forth and analysed the various AI technologies which are being currently used in Human resource management practices with reference to IT companies in Chennai. The study analysed the perception of HR employees towards AI technologies in HRM. The study demonstrated that the employees are totally having a positive perception towards the AI technologies and employees didn't perceive AI system as a treat to them. The study has strongly stressed the importance of AI technologies in the efficient function of HR department and to attain the competitive edge in the market. The research has also listed out the various factors which are holding back the implementation of AI system in HR practices. In conclusion, it is evident from the research that the employees are totally assertive about the AI technologies and they do believe that AI technologies are about to augment HR workforce in all possible ways. The study has also revealed that organisations should be consistently concentrating on implementing AI technologies in human resource management practices such as planning \& decision making, recruitment, training \& development, performance analysis and work-life balance.

\section{REFERENCES}

1. PwC (2018) Artificial intelligence in India - hype or reality Impact of artificial intelligence across industries and user groups https://www.pwc.in/assets/pdfs/consulting/technology/data-and-analytics/ artificial-intelligence-in-india-hype-or-reality/artificial-intelligence-in-indi a-hype-or-reality.pdf

2. Meghan M. Biro, CEO, TalentCulture (2017) The Impact of Technology on HR and what's Ahead https://www.huffpost.com/entry/the-impact-of-technology_b_9294208

3. Artificial Intelligence and its subsets and Applications 2019. https: www.brintia.com/artificial-intelligence - and- its-subsets-and applications/

4. https://www.guru99.com/expert-systems-with-applications.html.

5. Daniel Faggella, Founder and CEO at Emerj. Machine Learning in Human Resources - $\quad$ Applications and Trends https://emerj.com/ai-sector-overviews/machine-learning-in-human-resourc es/

6. Jessica Miller-Merrell (2019) How Artificial Intelligence (AI) is Changing Human Resources https://www.risesmart.com/blog/how-artificial-intelligence-ai-changing-h uman-resources

7. Seema Singh (2018) Cousins of Artificial Intelligencehttps://towardsdatascience.com/cousins-of-artificial-intelligen ce-dda4edc27b55

8. Manual Campos (2019) Applications of Machine Learning in Human Resources.

https://www.techedgegroup.com/blog/machine-learning-applied-to-human -resources

9. Shubham Panchal https://medium.com/predict/types-of-artificial-intelligence-and-examples4f586489c5de

10. Amit Paul Chowdhury, (2017) How different is Cognitive Computing from Artificial Intelligence? https://www.analyticsindiamag.com/different-cognitive-computing-artifici al-intelligence/

\section{AUTHORS PROFILE}

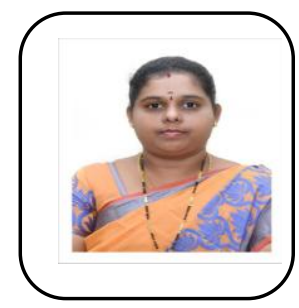

Dr. P. Barani Kumari, Research Supervisor Asst. Professor, Head, Department of Commerce (Honours), Sri Kanyaka Parameswari Arts And Science College For Women, Chennai - 01 Completed Ph.D., in Commerce (October 2015), SET EXAM QUALIFIED (October 2012), M.Phil in Commerce (2006 - 2007), Madurai Kamaraj University, Madurai. Master of Commerce (2004 - 2006) (Secured University Rank - 4), Sri Kanyaka Parameswari Arts And Science, College For Women, Chennai - 01. Bachelor of Commerce (2001-2004), Sri Kanyaka Parameswari Arts And Science, College For Women, Chennai - 01. Master of
Arts in Human Resource Management (2007 - 2009), Pondicherry University, Master of Business Administration (MBA) - Finance (2010-2012), University of Madras.

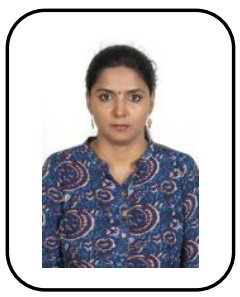

A. Hemalatha, Assistant professor, Department of Commerce, Sri Kanyaka Parameswari Arts And Science College For Women, Chennai - 01. Currently pursuing Ph.D. in Human Resource Management (Part-Time) in University of Madras, Chennai. Cleared UGC NET (National Eligibility Test for Assistant professor) June 2014 Examination and qualified. Business Studies/Commerce, General (M.Phil.) from University of Madras, Chennai. Business Studies /Commerce, General (M.com) from University of Madras, Chennai Business/Commerce, General (B.com) from University of Madras, Chennai. 